\title{
Uterine Leiomyoma and Reproductive Tract Infections Detected by Polymerase Chain Reaction
}

\author{
Geita Saadatnia ${ }^{1}$, Aboutaleb Saremi², Behrouz Salehian $^{3}$, Pirooz Salehian $^{4 *}$
}

1. Dept. of Biotechnology, Iranian Research Organization for Science and Technology (IROST), Tehran, Iran

2. Sarem Cell Research Center, Sarem Women's Hospital, Tehran, Iran

3. Dept. of Endocrinology, City of Hope National Medical Center, Duarte, California

4. Pathobiology Laboratory, Tehran, Iran

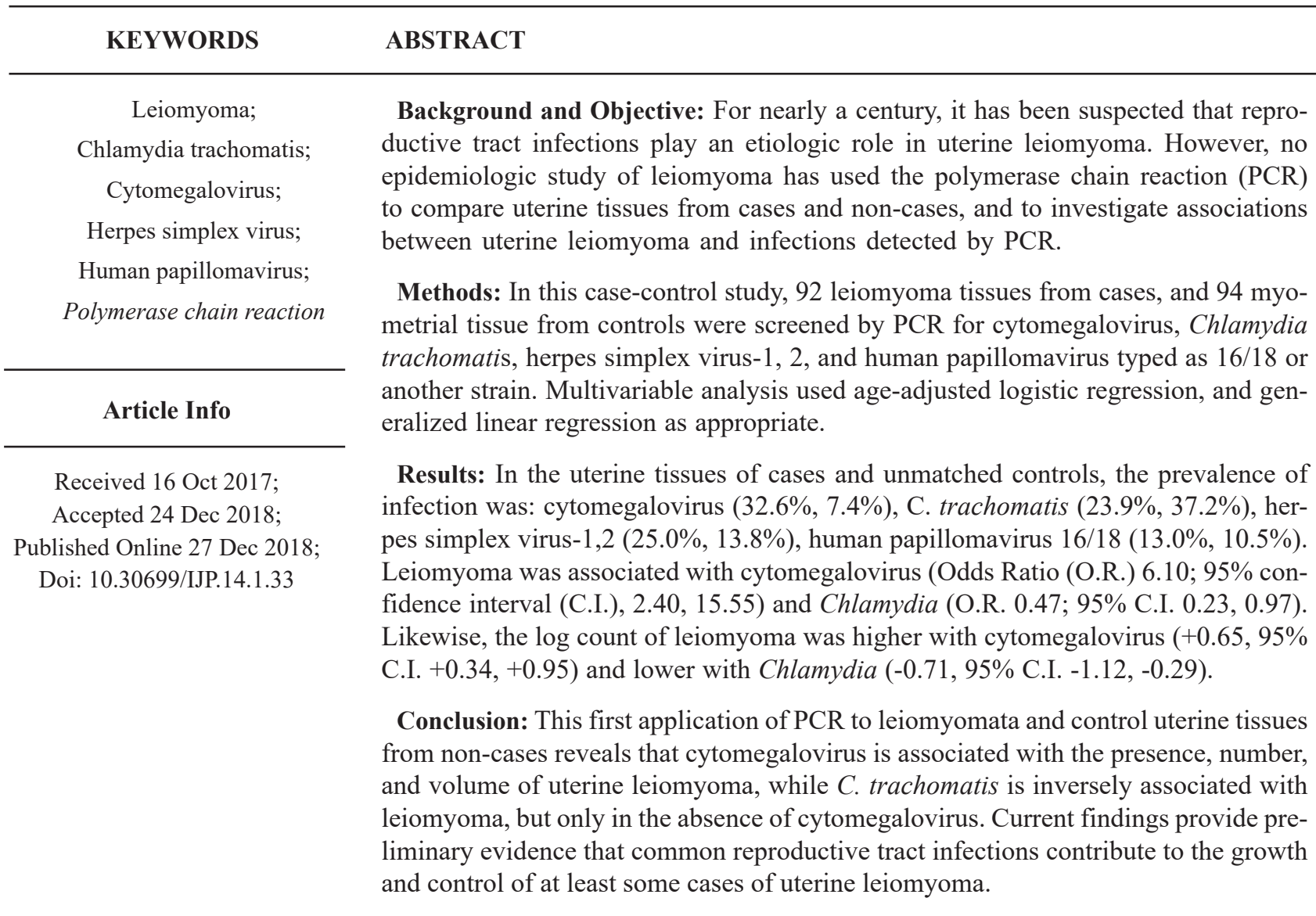

Corresponding Information:

Pirooz Salehian, Pathobiology Laboratory, Tehran, Iran. Email: piroozsalehian95@gmail.com

Copyright (C) 2019. This is an open-access article distributed under the terms of the Creative Commons Attribution-noncommercial 4.0 International License which permits copy and redistribute the material just in noncommercial usages, provided the original work is properly cited.

\section{Introduction}

By menopause, most women will have developed uterine leiomyoma (ta) (UL): according to ultrasound evidence, the cumulative incidence of UL by age 50 is nearly $70 \%$ among white women and more than $80 \%$ among African-American women (1). Asymptomatic in most cases, UL nevertheless causes infertility, pelvic pain, and severe menorrhea in a substantial proportion of women, frequently resulting in surgi- cal treatment (2-4). As a consequence, the economic burden of UL on the healthcare systems is substantial; costing between $\$ 5.9$ and $\$ 34.4$ billion annually in the United States alone (5). Despite the high cumulative incidence, significant morbidity, and major burden of UL on health and the economy, the pathogenesis of this disorder is not yet well understood.

For nearly a century, it has been suspected that reproductive tract infections (RTI) play an etiologic 
role in UL (6). According to a case-control study, the risk of UL increases with the number of self-reported episodes of pelvic inflammatory disease, with discontinuation of the intrauterine device due to infectious complications, and with the frequency of perineal talc use, from which findings it has been hypothesized that local uterine irritants of infectious or noninfectious origin contribute to the development of UL (7). However, it has proven difficult to detect infectious pathogens in UL $(8,9)$, although one laboratory succeeded in isolating cytomegalovirus (CMV) messenger RNA from the uterine tissue of UL cases (10).

Previous case-control studies of RTI and UL have been limited to self-reported history or serologic evidence of RTI. Specifically, among young AfricanAmerican women screened for UL using ultrasound, the self-reported history of "ever [having been] diagnosed with Chlamydia" has been associated with reduced risk of multiple UL (11). Among a similar population, serologic evidence of exposure to another RTI, herpes simplex virus (HSV) type 2, has been found to not be associated with the presence, number, or size of UL (12).

Recognizing the need to study whether laboratoryconfirmed uterine infections are associated with UL, we screened uterine tissues from pathology-confirmed UL cases and controls by polymerase chain reaction (PCR) for Chlamydia trachomatis, CMV, HSV type1,2, and human papillomavirus (HPV, categorized as 16/18 and non-16/18 strains). These pathogens were selected for study because of their affinity for the reproductive tract, prevalence in the adult female population, potential for persistent and/or asymptomatic infection, and in the case of HPV-16/18, leading causal role in tumors of the uterine cervix and anogenital tract (13).

\section{Materials and Methods}

\section{Subjects}

Approval to conduct this case-control study was obtained from the hospital's institutional review board. Eligible for study were patients aged 24-64 years who underwent gynecological surgery at this women's hos- pital during the period May 2013-March 2014. The leiomyoma status was determined through preoperative ultrasonography, and UL cases were confirmed by pathology. Written informed consent for the collection of clinical data and uterine tissue (leiomyoma tissue from cases, myometrial tissue from controls) was obtained prior to surgery. Cases included all patients who underwent surgery for pathology-confirmed uterine leiomyoma during the study period, and a similar number of consecutive, unmatched controls without UL who underwent endometrial curettage for abnormal bleeding, unexplained infertility, or uterine cyst. (Sample size is discussed below, under "statistical analysis".)

\section{Clinical Data}

For each case, the UL count and the dimensions of the largest UL were abstracted from the pathology report. Where the report indicated "more than $8 \mathrm{UL}$ ", a count of 10 was assigned for the current analysis. The height, width, and depth of the largest UL were converted into a spherical volume. Control subjects were assigned zero values for count and volume of UL. Age at surgery was abstracted from the medical chart. There was no missing data.

\section{Laboratory Testing}

PCR testing of uterine tissues was performed in mixed batches of cases and controls by laboratory personnel who were unaware of the case-control status of individual specimens. For DNA screening, 25-50 mg sections of formalin-fixed, paraffin-embedded tissue were studied. DNA extraction was performed with the High Pure PCR Template Preparation Kit (Roche, $\mathrm{GmbH}$, Germany), using the Human $\beta$-globin gene as a positive control for the extraction. DNA amplification was performed in a PCR thermocycler system (Primus 25 Thermal Cycler, USA) under the following conditions: Fast-Start Taq DNA polymerase activation at $96^{\circ} \mathrm{C}$ for 3 minutes, followed by 42 cycles of denaturation at $94^{\circ} \mathrm{C}$ for 60 seconds, annealing at $45^{\circ} \mathrm{C}$ for 90 seconds, and extension at $72^{\circ} \mathrm{C}$ for 90 seconds. PCR screening for HSV-1,2, CMV, and $C$. trachomatis was performed using pathogen-specific 
detection kits (DNA Technology, Moscow, Russia). Each kit included a positive control and distilled water as a negative control. Instead of a kit, initial PCR screening for HPV used consensus primers MY09: 5'CGTCCMARRGGAWACTGATC3' $\quad(\mathrm{R}=\mathrm{A} / \mathrm{C}$ $\mathrm{W}=\mathrm{A} / \mathrm{T} \quad \mathrm{M}=\mathrm{A} / \mathrm{T}$ ) and MY11: 5'GCMCAGGGWCATAAYAATGG3, $\quad(\mathrm{M}=\mathrm{A} / \mathrm{C} \quad \mathrm{W}=\mathrm{A} / \mathrm{T} \quad \mathrm{Y}=\mathrm{C} / \mathrm{T})$ and a 5- $\mu \mathrm{L}$ DNA template added to the master-mix (Cat No: K0171, Fermentas, EU). Specimens that tested positive for HPV were then screened for HPV type 16/18 (DNA Technology, Moscow, Russia).

\section{Statistical Analysis}

For this unmatched case-control study, sample size was chiefly determined by the availability of cases. Primary risk factors evaluated for univariable and multivariable association with UL were PCR-detected infection with CMV, C. trachomatis, HSV-1, 2, HPV type 16/18, and other HPV. Increasing age, being an established risk factor for UL in premenopausal women up to 50 years of age, was taken into account to control potential confounding of the primary associations. Because women over age 50 were not excluded from the current study, and because age as a continuous risk factor for UL has been documented only up to age 50, the association with years of age was currently analyzed as 2 risk factors: one for women under age 50 and one for women age 50 or older.

Associations with UL status were evaluated using unconditional logistic regression, for which there was $82 \%$ power (using 2 -sided testing and alpha $=0.05$ ) to detect a univariable odds ratio of 2.8 or greater for CMV, and 0.40 or lower for Chlamydia, given the prevalence of these infections among current cases. For risk factors significantly associated with UL, associations with UL count and volume of largest UL were evaluated using generalized linear regression with Poisson distribution and log link. In multivariable analysis, potential interactions between significant infections were explored and retained where significant $(\mathrm{P}<0.05)$. Due to the exploratory nature of the study, $p$ values were not adjusted for the testing of multiple hypotheses.

\section{Results}

Age and RTI prevalence among cases $(n=92)$ and controls $(n=94)$ are summarized in Table 1 . Among the cases, the UL count was $1(n=54), 2(n=16), 3$ $(n=5), 4-8(n=3)$, or more than $8(n=14)$, and the volume of the largest UL was median 92.9 (10th-90th percentile range 4.7-760.3) cubic centimeters.

The extracellular matrix (ECM), composed of proteoglycans (PGs), glycoproteins and collagens, is a well-organized structure with numerous physiological and pathological roles. $(3,4)$ Versican, a member of the aggregating chondroitin sulfate PGs family, is accumulated predominantly in the tumor stroma. Due

Table 1. Characteristics of Cases of Uterine Leiomyoma and Control Subjects

\begin{tabular}{|c|c|c|}
\hline Variable & $\begin{array}{l}\text { UL Cases }(\mathrm{n}=92) \\
\text { N (Column \%) }\end{array}$ & $\begin{array}{l}\text { Controls }(n=94) \\
\text { N (Column \%) }\end{array}$ \\
\hline \multicolumn{3}{|l|}{ Age, Years } \\
\hline $24-34$ & $44(47.8)$ & $60(63.8)$ \\
\hline $35-49$ & $46(50.0)$ & $27(28.7)$ \\
\hline $50-64$ & $2 \quad(2.2)$ & $7 \quad(7.5)$ \\
\hline \multicolumn{3}{|c|}{ Cytomegalovirus (CMV) } \\
\hline Positive & $30(32.6)$ & $7 \quad(7.4)$ \\
\hline Negative & $62(67.4)$ & $87(92.6)$ \\
\hline
\end{tabular}




\begin{tabular}{|c|c|c|}
\hline Variable & $\begin{array}{l}\text { UL Cases }(n=92) \\
\text { N (Column \%) }\end{array}$ & $\begin{array}{l}\text { Controls }(n=94) \\
\text { N (Column \%) }\end{array}$ \\
\hline \multicolumn{3}{|l|}{ Herpes Simplex Virus (HSV)-1,2 } \\
\hline Positive & $22(23.9)$ & $35(37.2)$ \\
\hline Negative & $70(76.1)$ & $59(62.8)$ \\
\hline \multicolumn{3}{|l|}{ Chlamydia trachomatis } \\
\hline Positive & $23(25.0)$ & $13(13.8)$ \\
\hline Negative & $69(75.0)$ & $81(86.2)$ \\
\hline \multicolumn{3}{|l|}{ Human Papillomavirus (HPV) } \\
\hline Positive for $16 / 18$ & $12(13.0)$ & $10(10.6)$ \\
\hline Positive but not for $16 / 18$ & $8 \quad(8.7)$ & $11(11.7)$ \\
\hline Negative & $72(78.3)$ & $73(77.7)$ \\
\hline \multicolumn{3}{|l|}{ Total Pathogens Present } \\
\hline 0 & $32(34.8)$ & $43(45.7)$ \\
\hline 1 & $36(39.1)$ & $30(31.9)$ \\
\hline 2 & $14(15.2)$ & $17(18.1)$ \\
\hline 3 & $9(9.8)$ & $4 \quad(4.3)$ \\
\hline 4 & $1(1.1)$ & 0 \\
\hline
\end{tabular}

The likelihood of UL was increased by CMV and decreased by Chlamydia; no significant association was detected with HSV-1, 2, HPV-16/18, and HPV non-16/18 (Table 2). The interaction between CMV and Chlamydia was undetectable in the model of UL likelihood but was significant in the models of UL count and volume of largest UL, indicating that, when both pathogens were present, the association with CMV remained and that it disappeared with Chlamydia (Table 3). The likelihood of UL, and the volume of largest the UL increased with age, but only before 50 years of age. (Tables 2 and 3) In contrast, the UL count increased with age to the same extent before and after age 50 (Table 3).

Table 2. Associations with Uterine Leiomyoma ( $\mathrm{N}=92$ Cases, 94 Controls)

\begin{tabular}{|c|c|c|c|c|}
\hline \multirow{2}{*}{ Risk Factors } & Univariable & \multirow{2}{*}{$P$} & Multivariable & \multirow{2}{*}{$P$} \\
\hline & Odds Ratio (95\% CI*) & & Odds Ratio (95\% CI*) & \\
\hline \multicolumn{5}{|l|}{ CMV } \\
\hline Positive & $6.01(2.48,14.57)$ & \multirow{2}{*}{$<0.0001$} & $6.10(2.40,15.55)$ & \multirow{2}{*}{0.0001} \\
\hline Negative & 1.00 & & 1.00 & \\
\hline \multicolumn{5}{|c|}{ Chlamydia trachomatis } \\
\hline Positive & $0.53(0.28,1.00)$ & 0.05 & $0.47(0.23,0.97)$ & 0.04 \\
\hline
\end{tabular}




\begin{tabular}{|c|c|c|c|c|}
\hline \multirow{2}{*}{ Risk Factors } & Univariable & \multirow{2}{*}{$P$} & Multivariable & \multirow{2}{*}{$P$} \\
\hline & Odds Ratio (95\% CI*) & & Odds Ratio (95\% CI*) & \\
\hline Negative & 1.00 & & 1.00 & \\
\hline \multicolumn{5}{|l|}{ HSV-1,2 } \\
\hline Positive & $2.08(0.98,4.41)$ & \multirow{2}{*}{0.06} & $1.71(0.75,3.93)$ & \multirow[t]{2}{*}{0.20} \\
\hline Negative & 1.00 & & 1.00 & \\
\hline \multicolumn{5}{|l|}{ HPV, By Viral Strain } \\
\hline Positive, Type 16/18 & $1.22(0.50,2.99)$ & 0.67 & $1.04(0.38,2.83)$ & 0.95 \\
\hline Positive, Not Type 16/18 & $0.74(0.28,1.94)$ & 0.54 & $0.59(0.19,1.80)$ & 0.35 \\
\hline Negative & 1.00 & & 1.00 & \\
\hline \multicolumn{5}{|l|}{ Per Additional Year of Age } \\
\hline If Aged Under 50 Years & $1.08(1.03,1.14)$ & 0.004 & $1.08(1.02,1.14)$ & 0.01 \\
\hline If Aged Over 50 Years & $0.98(0.93,1.04)$ & 0.51 & $0.86(0.57,1.30)$ & 0.47 \\
\hline
\end{tabular}

Table 3. Multivariable Models of Count and Volume of Uterine Leiomyoma, $\left(\mathrm{N}=186^{*}\right)$

\begin{tabular}{|c|c|c|c|c|}
\hline & $\begin{array}{c}\text { (log)Count of UL } \\
\text { Estimate }(95 \% \text { CI) }\end{array}$ & $\boldsymbol{P}$ & $\begin{array}{c}(\log ) \mathrm{cm}^{3} \text { Volume of } \\
\text { Largest UL, } \\
\text { Estimate }(95 \% \mathrm{CI})\end{array}$ & $\boldsymbol{P}$ \\
\hline $\begin{array}{l}\text { Mean Value among Women Age } 35 \text { and } \\
\text { Negative for CMV and C. trachomatis }\end{array}$ & $0.55(0.33,0.78)$ & ---- & $4.81(4.76,4.85)$ & ---- \\
\hline $\begin{array}{l}\text { Difference in Mean Value Associated With: } \\
\text { CMV and C. trachomatis Status }\end{array}$ & & 0.02 & & $<0.0001$ \\
\hline CMV-Positive, Chlamydia-Negative $(n=24)$ & $+0.65(+0.34,+0.95)$ & & $+0.30(+0.27,+0.33)$ & \\
\hline CMV-Positive, Chlamydia-Positive $(n=13)$ & $+0.65(+0.06,+1.24)$ & & $+0.36(+0.29,+0.44)$ & \\
\hline CMV-Negative, Chlamydia-Positive $(n=44)$ & $-0.71(-1.12,-0.29)$ & & $-1.38(-1.44,-1.33)$ & \\
\hline CMV-Negative, Chlamydia-Negative $(n=105)$ & 0 & & 0 & \\
\hline
\end{tabular}

Per Additional Year of Age

$\begin{array}{ccccc}\text { If Aged Under } 50 \text { Years }(\mathrm{n}=177) & +0.03(+0.01,+0.06) & 0.002 & \begin{array}{c}+0.099(+0.097, \\ +0.101)\end{array} & <0.0001 \\ \text { If Aged Over } 50 \text { Years }(\mathrm{n}=9) & +0.03(+0.01,+0.05) & 0.002 & -0.005(-0.009,-0.001) & 0.01\end{array}$

Subjects without uterine leiomyoma (UL) were assigned zero values for count and volume. 


\section{Discussion}

This is the first case-control study of UL to employ PCR to detect pathogens in uterine tissue. According to this study, the DNA of at least one RTI is present in the uterus of the majority of women undergoing gynecologic surgery, whether or not the procedure is undertaken to treat UL. Moreover, two of the more prevalent uterine infections, CMV and C. trachomatis, are significantly and consistently associated with the presence, count, and volume of UL.

The current association of UL with CMV is a novel finding, for which there is supportive biological evidence. In 10 out of 10 UL cases in a pathology study, CMV messenger RNA was isolated from the muscular layers of the uterus, namely from fibroblasts and smooth muscle cells (10). Myofibroblasts, cells of an intermediate phenotype between normal uterine muscle and differentiated fibroblasts (14), are active in both keloid scars and uterine fibroids, disorders of extracellular matrix formation that were recently recognized as having similar ultrastructure and gene expression profiles on microarray (15). In both disorders, myofibroblasts become arrested in the proliferation stage of tissue repair (15). CMV has also been associated with excessive proliferation of smooth muscle cells within blood vessels (specifically, vessels injured during coronary angioplasty, resulting in restenosis) (15). Taken together, these studies suggest that CMV infection of the uterus may promote local myofibroblast activity and tissue proliferation, resulting in one or more UL.

The current inverse association of $C$. trachomatis with UL confirms and expands upon a prior report that multiple UL are less often present among women who report a history of Chlamydia (11). Two other case-control studies of UL did not detect an association with Chlamydia, possibly because subjects in those studies had a very low prevalence of that infection $(7,8)$. According to our analyses of counts and volume of UL, when both CMV and Chlamydia are present, the association with CMV prevails over that with Chlamydia. The current study also confirms a recent report that HSV-2 is not associated with UL (12).
We interpret our findings as preliminary evidence that CMV may promote the development of a subset of UL cases and that local response to Chlamydia may protect against UL cases not associated with CMV. If this interpretation is confirmed by biological studies, then it suggests a novel potential strategy to reduce the incidence and associated morbidity of UL, namely combined vaccination against CMV and C. trachomatis early in life. At present, there are no approved vaccines against CMV or Chlamydia. However, Phase II trials have been completed for several vaccines against $\mathrm{CMV}$, one of which is currently in Phase III testing (17). Vaccine development for Chlamydia is at a much earlier stage, but recent work is promising: mucosal (intrauterine or intranasal) immunization with ultraviolet light-inactivated $C$. trachomatis conjugated to adjuvant nanoparticles has induced long-lived genital protection in both conventional and humanized mice by seeding the uterine mucosa with effector $\mathrm{T}$ cells that establish resident memory $\mathrm{T}$ cells (18).

A chief limitation of this study is its cross-sectional design, which demonstrates association but does not indicate the relative timing of infections and UL. Nevertheless, the case-control design is widely used for the first study of any novel risk factor in order to generate preliminary findings that can inform future prospective studies. Another current limitation is the lack of serologic testing for the same RTI screened in uterine tissue by PCR. A comparison of serologic versus PCR findings would have been useful to identify, for example, subjects previously exposed to C. trachomatis but currently PCR-negative, or those with serologic evidence of CMV but without uterine infection by the virus. In addition, all current cases had UL requiring surgical intervention; thus, it remains to be studied whether current findings are generalizable to UL that are asymptomatic or not sufficiently burdensome to require treatment. Case reports have linked some cases of UL to parasites responsible for Chagas' disease (19) and schistosomiasis (20). For practical reasons, we studied only pathogens commonly found in the reproductive tract of women worldwide. Finally, the current study lacked data on covariates other than age and drew its subjects from a single institu- 
tion and ethnic group. Confirmatory epidemiological studies without these current limitations are needed.

To establish roles for CMV and Chlamydia in UL, confirmatory biological studies will also be required to elucidate the mechanisms by which these infections may promote (in the case of CMV) or limit (in the case of Chlamydia) the growth of uterine leiomyoma. It may be informative to investigate potential associations between the CMV and Chlamydia status and the recently identified molecular subclasses of UL, which are distinguished by mutually exclusive genetic mutations, including high mobility group AThook 2 (HMGA2) rearrangements, mediator complex

\section{References}

1. Baird D, Dunson DB, Hill MC, Cousins D, Schectman JM. High cumulative incidence of uterine leiomyoma in black and white women: ultrasound evidence. Am J Obstet Gynecol. 2003;188:100-7. https:// doi.org/10.1067/mob.2003.99 PMID: 12548202

2. Pritts EA, Parker WH, Olive DL. Fibroids and infertility: an updated systematic review of the evidence. Fertil Steril. 2009;91:1215-23. https://doi.org/10.1016/j. fertnstert.2008.01.051 PMID:18339376

3. Lippman SA, Warner M, Samuels S, Olive D, Vercellini P, Eskenazi B. Uterine fibroids and gynecologic pain symptoms in a population-based study. Fertil Steril. 2003; 80:1488-94. https://doi.org/10.1016/ S0015-0282(03)02207-6

4. Wegienka G, Baird DD, Hertz-Picciotto I, Harlow SD, Steege JF, Hill MC, et al. Self-reported heavy bleeding associated with uterine leiomyomata. Obstetrics \& Gynecology. 2003;101(3):431-7.

5. Cardozo ER, Clark AD, Banks NK, Henne MB, Stegmann BJ, Segars JH. The estimated annual cost of uterine leiomyomata in the United States. Am J Obstet Gynecol. 2012;206:211.e1-9. https://doi. org/10.1016/j.ajog.2011.12.002 PMID:22244472 PMCID:PMC3292655

6. Witherspoon JT, Butler VW. The etiology of uterine fibroids with special reference to the frequency of their occurrence in the Negro: A hypothesis. Surg Gynecol Obstet. 1934;58:4. subunit 12 (MED12) mutations, biallelic inactivation of fumarate hydratase $(\mathrm{FH})$, and type IV alpha 5 and alpha 6 collagen (COL4A5-COL4A6) deletions (21).

\section{Acknowledgments}

The authors are grateful to Mrs. Samira Rezaei of Sarem Women's Hospital, Tehran, Iran, for assistance with data collection.

\section{Conflict of Interest}

The authors declare that there is no conflict of interest in the publication of this paper.

7. Faerstein E, Szklo M, Rosenshein NB. Risk factors for uterine leiomyoma: a practice-based casecontrol study. II. Atherogenic risk factors and potential sources of uterine irritation. Am J Epidemiol 2001;153:11-9. https://doi.org/10.1093/aje/153.1.11 PMID: 11159140

8. Laughlin SK, Schroeder JC, Baird DD. New directions in the epidemiology of uterine fibroids. Semin Reprod Med. 2010;28:204-17. https://doi. org/10.1055/s-0030-1251477 PMID:20414843 PMCID:PMC5330647

9. Kocjan BJ, Seme K, Poljak M. Comparison of the Abbott RealTime High Risk HPV test and INNOLiPA HPV Genotyping Extra test for the detection of human papillomaviruses in formalin-fixed, paraffin-embedded cervical cancer specimens. J Virol Methods. 2011;175:117-9. https://doi.org/10.1016/j. jviromet.2011.04.006 PMID:21513740

10. Furukawa T, Jisaki F, Sakamuro D, Takegami T, Murayama $\mathrm{T}$. Detection of human cytomegalovirus genome in uterus tissue. Arch Virol. 1994;135:265-77. https://doi.org/10.1007/BF01310013 PMID:7979967

11. Moore KR, Cole SR, Dittmer DP, Schoenbach VJ, Smith JS, Baird DD. Self-reported reproductive tract infections and ultrasound diagnosed uterine fibroids in African-American women. J Womens Health (Larchmt). 2015;24:489-95. https://doi.org/10.1093/ aje/kwv313 PMID:27188945 PMCid:PMC4887579

12. Moore KR, Smith JS, Cole SR, et al. Herpes sim- 
plex virus type 2 seroprevalence and ultrasounddiagnosed uterine fibroids in a large population of young African-American women. Am J Epidemiol . 2016;183:961-8. https://doi.org/10.1093/aje/kwv313 PMID:27188945 PMCID:PMC4887579

13. Haedicke J, Iftner T. Human papillomaviruses and cancer. Radiother Oncol. 2013;108:397-402 PMID:23830197

14. Desmouliere A, Chaponnier C, Gabbiani G. Tissue repair, contraction, and the myofibroblast. Wound Rep Reg. 2005;13:7-12. https://doi.org/10.1111/ j.1067-1927.2005.130102.x PMID: 15659031

15. Leppert PC, Catherino WH, Segars JH. A new hypothesis about the origin of uterine fibroids based on gene expression profiling with microarrays. Am J Obstet Gynecol. 2006;195:415-20. https://doi. org/10.1016/j.ajog.2005.12.059 PMID:16635466 PMCid:PMC4143906

16. Speir E, Modali R, Huang ES, Leon MB, Shawl F, Finkel T, Epstein SE. Potential role of human cytomegalovirus and p53 interaction in coronary restenosis. Science. 1994 Jul 15;265(5170):391-4. https:// doi.org/10.1126/science.8023160 PMID: 8023160

17. Rieder F, Steininger C. Cytomegalovirus vac- cine: phase II clinical trial results. Clin Microbiol Infect 2014;20 Suppl 5:95-102. https://doi. org/10.1111/1469-0691.12449 $\quad$ PMID:24283990 PMCID:PMC5716458

18. Stary G, Olive A, Radovic-Moreno AF, et al. A mucosal vaccine against Chlamydia trachomatis generates two waves of protective memory T cells. Science 2015;348:8205. $\quad$ https://doi.org/10.1126/science. aaa8205 PMID:26089520 PMCid:PMC4605428

19. Murta EF, Oliveira GP, Prado F de O, De Souza MA, Tavares Murta BM, Adad SJ. Association of uterine leiomyoma and Chagas' disease. Am J Trop Med Hyg 2002;66:321-4. https://doi.org/10.4269/ajt$\underline{\text { mh.2002.66.321 }}$ PMID: 12139229

20. Adeleye JA, Odjegba A. Schistosomiasis of the uterus in association with uterine fibroids. Trop Geogr Med. 1975;27:206-8.

21. Mehine M, Kaasinen E, Heinonen HR, et al. Integrated data analysis reveals uterine leiomyoma subtypes with distinct driver pathways and biomarkers. Proc Natl Acad Sci U S A. 2016;113:1315-20. https:// doi.org/10.1073/pnas.1518752113 PMID:26787895 PMCID:PMC4747776

\section{How to Cite This Article}

Saadatnia G, Saremi A, Salehian B, Salehian P. Uterine Leiomyoma and Reproductive Tract Infections Detected by Polymerase Chain Reaction. Iranian Journal of Pathology. 2019; 14(1): 33-40. 